\title{
Constitutionalizing Connectivity The Constitutional Grid of World Society
}

\author{
Kjær, Poul F.
}

Document Version

Accepted author manuscript

Published in:

Journal of Law and Society

DOI:

10.1111/jols.12106

Publication date:

2018

License

Unspecified

Citation for published version (APA):

Kjær, P. F. (2018). Constitutionalizing Connectivity: The Constitutional Grid of World Society. Journal of Law and Society, 45(S1), S114-S134. https://doi.org/10.1111/jols.12106

Link to publication in CBS Research Portal

\section{General rights}

Copyright and moral rights for the publications made accessible in the public portal are retained by the authors and/or other copyright owners and it is a condition of accessing publications that users recognise and abide by the legal requirements associated with these rights.

Take down policy

If you believe that this document breaches copyright please contact us (research.lib@cbs.dk) providing details, and we will remove access to the work immediately and investigate your claim. 


\title{
Constitutionalizing Connectivity: The Constitutional Grid of World Society
}

\author{
Poul F. Kjaer \\ Journal article (Accepted manuscript*)
}

\section{Please cite this article as:}

Kjær, P. F. (2018). Constitutionalizing Connectivity: The Constitutional Grid of World Society. Journal of Law and Society, 4SS1), S114-S134. D0l: 10.1111/jols.12106

This is the peer reviewed version of the article, which has been published in final form at DOI:

https://doi.org/10.1111/jols.12106

This article may be used for non-commercial purposes in accordance with Wiley Terms and Conditions for SelfArchiving

* This version of the article has been accepted for publication and undergone full peer review but has not been through the copyediting, typesetting, pagination and proofreading process, which may lead to differences between this version and the publisher's final version AKA Version of Record. 


\title{
CONSTITUTIONALIZING CONNECTIVITY: THE CONSTITUTIONAL GRID OF WORLD SOCIETY
}

\author{
Poul F. Kjaer* \\ Copenhagen Business School
}

\begin{abstract}
Global law settings are characterised by a structural pre-eminence of connectivity norms, a type of norm which differs from coherency or possibility norms. The centrality of connectivity norms emerges from the function of global law, which is to increase the probability of transfers of condensed social components, such as economic capital and products, religious doctrines and scientific knowledge, from one legally structured context to another within world society. This was the case from colonialism and colonial law to contemporary global supply chains and human rights. Both colonial law and human rights can be understood as serving a constitutionalising function aimed at stabilising and facilitating connectivity. This allows for an understanding of colonialism and contemporary global governance as functional, but not as normative, equivalents.
\end{abstract}

\section{INTRODUCTION}

The notion of world society, i.e., the proposition that only one society exists in our world, stipulates a potential of connectivity on a global scale. Originally developed on the

\footnotetext{
Professor, Department of Management, Politics and Philosophy, Copenhagen Business School, Porcelaenshaven 18B, 2000 Frederiksberg, Denmark. Email: pfk.mpp@cbs.dk. Orcid:0000-0002-80273601.

This is a translated and revised version of 'Constitutionalizing Connectivity: The Constitutional Grid of World Society', Journal of Law and Society, 45, S1, 114 - 34, 2018. Earlier versions was presented at the conferences "Societal Constitutions in Transnational Regimes", Cardiff University, 30 June - 1 July 2017 and "The politics of (dis)connectivity", Chinese Academy of Sciences, Beijing, 30 November - 1 December 2017. The research leading to this article was developed with support of the European Research Council ITEPE-312331.
} 
basis of the Husserlian notion of common horizons of opportunity, the concept of world society however remains very general in nature. ${ }^{1}$ Giving substance to the notion of world society, this article cultivates an understanding of global legal norms as instruments of connectivity which play a significant role in the realisation of world society. Drawing on a rich literature concerning the function of legal norms, the perspective will be developed that legal norms not only limit connectivity but also serve as enablers of connectivity. This is central for our understanding of the position and function of global legal norms, as world society, paradoxically, consists of many worlds. World society is an a-centric society which is not only horizontally differentiated between functionally delineated fields (or 'systems'), but also vertically differentiated between social processes relying on local, national and transnational organising principles. ${ }^{2}$ Also paradoxically, increased globalisation has, furthermore, resulted in an increase, rather than a demise, of contextual diversity. The logic of differentiation associated with the a-centric world society therefore has to be complemented by logic of connectivity. It is on this background that global legal norms have emerged as instruments of connectivity.

Apart from the classical function of norms in relation to the stabilisation of expectations, global legal norms are specifically aimed at the structuration of transfers, i.e., the extraction, transmission and implantation of condensed social components (Sinnkomponente) from one context to another. This is the case in relation to all functionally delineated fields in so far as such transfers can be observed in relation to political decisions, legal judgments, economic capital and products, scientific knowledge, and so forth. It is through their orientation towards such transfers that global legal norms obtain a role as connectivity-enhancing instruments.

This is also reflected in the evolutionary transformation of the legal norms aimed at stabilising globally unfolding processes. One of the most central, perhaps the most central, structural transformation which contemporary law and social sciences is grabbling with, is the still ongoing de-centring of the world after the implosion of the euro-centric world and the still ongoing erosion of the western-centric world. This transformation has not yet been

\footnotetext{
N. Luhmann, "Die Weltgesellschaft", (1971) 57 Archiv für Rechts- und Sozialphilosophie, pp. 1-35. Reprinted in N. Luhmann, Soziologische Aufklärung 2. Aufsätze zur Theorie der Gesellschaft, (Opladen: Westdeutsche Verlag [1975] 2009), pp. 51-71.

2 S. Sassen, Territory • Authority • Rights: From Medieval to Global Assemblages, (Princeton NJ: Princeton University Press, 2006).
} 
fully conceptually and empirically understood leaving the world in a vacuum of uncertainty. ${ }^{3}$ Looking specifically at the institutionally embedded legal infrastructure of world society, this transformation can also be understood as a structural transformation from colonialism to contemporary transnational governance. Both colonialism and contemporary transnational governance go far beyond a mere focus on the economy, while, at the same time, the structuring of economic transfers remains central to both. ${ }^{4}$ Zooming in on the economic dimension in this article, one might empirically observe a shift from the economic dimension of colonialism to global supply chains as the central change in the structuring of global processes of economic transfers. Both colonialism and contemporary global supply chains rely on legal instruments, and both are characterised by a hierarchy of norms, which enable one to speak of their constitutionalisation. The substantial norms upon which they rely are, however, very different thereby allowing for an understanding of the economic dimension of colonialism and global supply chains as functional, but not as normative, equivalents. Or, to express it differently: The transformation from colonialism to global supply chains implied a fundamental shift in the constitutional grid of world society.

The article proceeds as follows: the first two steps are context denoting exercises, briefly outlining the contours of world society and of global law. This is followed by the location of the approach advanced within the existing theoretical landscape highlighting the ambition to carve a path between unifying and radical pluralist approaches to global law. This ambition is substantiated in the two subsequent steps through the development of the notion of connectivity norms as a particular type of legal norms which, for structural reasons, tend to gain prominence in relation to globally unfolding social processes and through a brief reconstruction of the central stages of the transformation from the economic dimension of colonialism to global supply chains. The article ends with a discussion of the implications of the findings for our understanding of constitutionalism in world society.

\section{The Societal Context: The Emergence of World Society}

The concept of world society was introduced by Niklas Luhmann in the early 1970s, encapsulating a whole string of developments which, several decades later, became part of

3 H. Brunkhorst, "Constitutionalism and Democracy in the World Society", in Petra Dobner and Martin Loughlin (eds), The Twilight of Constitutionalism?, (Oxford: Oxford University Press, 2010), pp. 179-198, $185 \mathrm{f}$.

4 M. Xifaras, "The Global Turn in Legal Theory", (2016) XXIX Canadian Journal of Law \& Jurisprudence, pp. 215-243, at 219f. 
the broader narrative on globalisation. ${ }^{5}$ The core element of Luhmann's concept of world society is the Husserlian concept of intentional horizons, ${ }^{6}$ to which he gave a twist by arguing that, in world society, the social world in its entirety share a common pool of potential experiences. As such, Luhmann stipulated a process characterised by a fusion of horizons (Horizontverschmelzung) in the sense of Gadamer. As the concept of horizons are embedded in - and indeed constituted in - time, this development is furthermore closely linked to the emergence of world time as developed in the latter half of the nineteenth century, i.e., a unitary concept of time enabling communication throughout the world without losing time.

Historically, one might identify three phases in the historical emergence of world society: first, the European discovery of the world as a singular globe in the wake of the scientific and exploratory sightings of the fifteenth and sixteenth centuries and the concordant development of a singular - euro-centric - legal order claiming validity for the world in its entirety. ${ }^{9}$ Second, the emergence of a synchronised world which, as already mentioned, manifested itself in the emergence of world time from the 1850s onwards, a development which took place in the wake of technological changes, such as those related to the steam ship, the railways and the telegraph, as well as the second wave of European (and Japanese and US-American) imperialist expansion leading to the succumbing of the world in its entirety to globally unfolding and connected processes. ${ }^{10}$ This is expressed in the globalisation of functional fields, i.e. social systems, in relation to the economy, law, the mass media, politics, science and so forth, and is also reflected in semantic articulations such as the "world economy", "world politics" and "world literature". 11 Third: the intensification

5 For the Bielefeld school on world society, see R. Stichweh, Die Weltgesellschaft: Soziologische Analysen, (Frankfurt am Main: Suhrkamp Verlag, 2000). For the Stanford school, see J.W. Meyer, J. Boli, G.M. Thomas and F.O. Ramirez, "World Society and the Nation-State", American Journal of Sociology, 1997, 103, pp. 144-181.

6 N. Luhmann, "Die Weltgesellschaft", (1971) 57 Archiv für Rechts- und Sozialphilosophie, pp. 1-35. Reprinted in N. Luhmann, Soziologische Aufklärung 2. Aufsätze zur Theorie der Gesellschaft, (Opladen: Westdeutsche Verlag [1975] 2009), pp. 51-71.

7 H.-G. Gadamer, Wahrheit und Methode, Gesammelte Werke, Band I, (Tübingen: Mohr Siebeck, 1986), p. $310 \mathrm{ff}$.

8 N. Luhmann, Die Gesellschaft der Gesellschaft, (Frankfurt am Main: Suhrkamp Verlag, 1997), p. 145ff.

9 P.F. Kjaer, Constitutionalism in the Global Realm - A Sociological Approach, (Abingdon: Routledge, 2014 - Paperback 2016); C. Schmitt, Der Nomos der Erde. Im Völkerrecht des Jus Publicum Europaeum, (Berlin:

10 Duncker \& Humblot, 1950)

J. Osterhammel, The Transformation of the World: A Global History of the Nineteenth Century, (Princeton NJ: Princeton University Press, 2014). Translated from German by Patrick Camiller.

11 R. Stichweh, "Das Konzept der Weltgesellschaft: Genese und Strukturbildung eines globalen Gesellschaftssystems”, (2008) 39 Rechtstheorie, pp. 329-55. 
of these processes from the 1960s onwards through steady increases in global communication flows in the wake of new technologies, such as container shipping, satellite communication, and the Internet, as well as profound changes in the legal and regulatory set-ups, as, for example, reflected in the liberalisation of capital flows during the last decades of the twentieth century, which led to a massive intensification of social exchanges with a global reach.

However, in spite of this development, the concept of world society remains underdetermined. $^{12}$ Functionally delineated fields or systems with a global reach do exist today as testified by the global financial systems, global mass media, global science and so forth. This indicates that functional differentiation has become the central organising principle of world society with the consequence that other forms of differentiation such as centre/periphery, stratification and segmentary differentiation increasingly become internal, and thus secondary forms of differentiation unfolding within functionally-delineated fields. This is, for example, reflected in stratified global rankings within the area of higher education or the reliance on centre/periphery for the organisation of global finance through the City in London and Wall Street within the economic system. Questions, however, arise concerning the depth and degree of advancement of this development. The parts of the world where modernity, defined as the primacy of functional differentiation, ${ }^{13}$ has gained outright dominance remain limited to a rather small part of the world, most notably the North Atlantic area. Global cities characterised by strong elements of modernity exist throughout the world, ${ }^{14}$ but, in the most parts of the world, functional differentiation continues to stand in an orthogonal relationship to other forms of differentiation, i.e., centre/periphery, segmentary and stratificatory differentiation, in a manner which makes the thesis of an outright dominance of functional differentiation empirically questionable. ${ }^{15}$ This might, of course, merely be a matter of "causality in the south". ${ }^{16}$ But social evolution is blind and no guarantee exists for a future duplication of the modernisation which unfolded in large segments of Europe and North America in the rest of the world. Only the current condition

12 M. Amstutz and V. Karavas, "Weltrecht: Ein Derridasches Monster", in Gralf-Peter Calliess, Andreas Fischer-Lescano, Dan Wielsch and Peer Zumbansen (eds), Soziologische Jurisprudenz. Festschrift für Gunther Teubner zum 65. Geburtstag, (Berlin: Walter de Gruyter, 2009), pp. 645-672.

13 N. Luhmann, Die Gesellchaft der Gesellschaft, (Frankfurt am Main: Suhrkamp Verlag, 1997), p. 145ff.

14 S. Sassen, The Global City: New York, London, Tokyo, (Princeton NJ: Princeton University Press, 2001).

15 M. Neves, Verfassung und Positivität des Rechts in der peripheren Moderne, (Berlin: Duncker \& Humblot, 1992).

16 N. Luhmann, “Kausalität im Süden”, (1995) 1 Soziale Systeme, pp. 7-28. 
remains observable, a condition which can also be seen as characterised by métissage and creolisation, i.e., a mixing of different types of communication, in a manner which evades claims to the "purity" of communication. ${ }^{17}$ So, although functional fields operating on specific internal logics do have global reach, they operate, in most contexts, in a manner which is characterised by a limited degree of distillation and only act as a thin layer of varnish spread out "on top" of far more deep-seated forms of communication. ${ }^{18}$ This is, for example, observable in post-colonial contexts in which in-between spaces have emerged between the operations of formalised frameworks imposed from the outside and the preexisting logics of organising communication.

\section{The Legal Context: The Emergence of Global Law}

The gradual emergence of, and intensification of, social exchanges within world society has been accompanied by, and, to a large extent, also been created by, a concordant appearance of global law as an emerging legal field. Emergent in so far as it still remains "incomplete", making it a legal phenomenon, rather than a fully-fledged legal system in its own right. ${ }^{20}$ This is the case as the delineation of the phenomenon of global law vis-à-vis national, international, transnational, as well as local community-based law remains blurred. National law has, from a classical positivist perspective, been understood as the internal law of nation states as derived from the concept of sovereignty. Classical international law is, as a reflection of the concept of national law, typically understood as the law between states, allowing for a conceptual exclusion of types of law, or law-like, phenomena which do not fit into its inter-state conceptual frame. ${ }^{21}$ Transnational law can be understood as a category of

17 M. Amstutz, "Métissage. Zur Rechtsform in der Weltgesellschaft", in Andreas Fischer-Lescano, Florian Rödl and Christoph U. Schmid (eds), Europäische Gesellschaftsverfassung. Zur Konstitutionalisierung sozialer Demokratie in Europa, (Baden-Baden: Nomos Verlag, 2009), pp. 333-351; P.F. Kjaer, "Law of the Worlds - Towards an Inter-SystemicTheory", in Stefan Keller and Stefan Wipraechtiger (eds), Recht zwischen Dogmatik und Theorie. Marc Amstutz zum 50. Geburtstag, (Zürich: Dike Verlag, 2012), pp. 15975.

18

P.F. Kjaer, "Law of the Worlds - Towards an Inter-SystemicTheory", in Stefan Keller and Stefan Wipraechtiger (eds), Recht zwischen Dogmatik und Theorie. Marc Amstutz zum 50. Geburtstag, (Zürich: Dike Verlag, 2012), pp. 159-75.

19 M. Amstutz, "Métissage. Zur Rechtsform in der Weltgesellschaft", in Andreas Fischer-Lescano, Florian Rödl and Christoph U. Schmid (eds), Europäische Gesellschaftsverfassung. Zur Konstitutionalisierung sozialer Demokratie in Europa, (Baden-Baden: Nomos Verlag, 2009), pp. 333-351; A. Mbembe, “Qu'estceque la pensée postcoloniale?", Esprit, 2006. P. Le Golf, "Global Law: A Legal Phenomenon Emerging from the Process of Globalization", (2007) 14 Indiana Journal of Global Legal Studies, pp. 119-145.

21 J. Klabbers, "Of Round Pegs and Square Holes: International Law and the Private Sector”, in Paulius Jurčys, 
any law which, one way or the other, i.e., in terms of jurisdiction, source or effect, crosses national borders. Hence, transnational law, in its original meaning, mainly - though not exclusively - refers to the external effects of national law. ${ }^{22}$ It is against this background that the more recent notion of global law has emerged. Global law can, following Neil Walker, refer to the mere rhetorical usage of the term "Global", for example, by law firms that stage themselves as global actors. It can refer to a specific type of law with a (near to) global reach, mainly referring to globally-acting institutions such as the United Nations or the World Trade Organization. In contrast to such perspectives, Walker, however, conceptualises global law as any type of law, irrespective of its origin or orientation, which in principle is, or can be, unlimited in its reach. Thus, global law claims - or can potentially claim - validity without reference to or the limitations of a specific territory or population, although, for material and practical reasons, it will be limited in most cases. ${ }^{23}$ Against this background, Walker considers EU law to represent the incarnation of global law, as it operates in a manner which means it is not strictly linked to territorial delineations just as there are, in principle, no limitations to its reach. ${ }^{24}$

While this universalising dimension is a central feature of global law, one might, however, add two additional dimensions which give additional substance to the notion: inbetweenness and transfer. The basic structure of world society is characterised by functionally delineated fields or systems with a global reach while nonetheless being faced with substantial indeterminacy in most parts of the world concerning the relationship between the different logics of differentiation. In particular, although not just for the global fields of law and politics, this is expressed through a three-layer world. World society is not only characterised by a horizontal fixation of functionally delineated fields but is also

Poul F. Kjaer and Ren Yurakami, Regulatory Hybridization in the Transnational Sphere, (Leiden: Brill Publishing, 2013), pp. 29-48.

22 N. Walker, Intimations of Global Law, (Cambridge: Cambridge University Press, 2015); P. Jessup, Transnational Law (New Haven CT: Yale University Press, 1956); M. Avbelj, "The Concept and Conceptions of Transnational and Global Law”, WZB Discussion Paper SP IV 2016-801, February 2016, p. 9.

23

M. Avbelj, "The Concept and Conceptions of Transnational and Global Law", WZB Discussion Paper SP IV 2016-801, February 2016, p. 9.

N. Walker, Intimations of Global Law, (Cambridge: Cambridge University Press, 2015). For a critique of "boundaryless law", see A. Supiot, "The Territorial Inscription of Laws", in Gralf-Peter Calliess, Andreas Fischer-Lescano, Dan Wielsch and Peer Zumbansen (eds), Soziologische Jurisprudenz. Festschrift für Gunther Teubner zum 65. Geburtstag am 30. April 2009, (Berlin: Walter de Gruyter Verlag, 2009), pp. 37593. 
characterised by a vertical layering between local, national and transnational processes. ${ }^{25}$ It is in this complex matrix that a multitude of observations, transfers and collisions between contextually-embedded units located both within the same layer and within different layers takes place. Global law can thus be defined as a universally applicable legal phenomenon of the "in-between", ${ }^{26}$ which is materially aimed at facilitating the separation, transmission and incorporation of social components from one legally-structured context to another. Global law might, therefore, also be understood as a decentred phenomenon manifested in interlegality, ${ }^{27}$ which is universal in so far as it can appear in an infinite number of settings throughout the globe at the same time as it is a type of law which produces autonomous effects on the world.

\section{The Approach: Carving a Third Way between Unification and Pluralism}

Global law relies on and combines elements from local, national, international and transnational law, while also reproducing legal figures of its own. International public law, defined as the rules and norms guiding relations between governments and other state entities, as well as private international law, understood as rules for selecting the applicable law and type of contract in cross-border constellations, including the issue of court competence in cases of dispute, ${ }^{28}$ can both serve as vehicles of global law. The same goes for the academic discipline of comparative law which has, at its core element, the comparison of different legal systems, and, as such, provides a foundation for the divergences which international public and private law focuses upon and thus also provides for any possible harmonisation efforts. As such, comparative law, as an academic discipline, can be seen as producing performative effects which are essential for global law. International economic law, defined as the rules and norms guiding cross-border economic transactions and including sub-fields such as trade and investment law, as well as the disputed phenomenon of Lex Mercatoria, the body of principles guiding cross-border commercial contracts, are also

25 S. Sassen, Territory • Authority • Rights: From Medieval to Global Assemblages, (Princeton NJ: Princeton University Press, 2006); Terence C. Halliday and Gregory Shaffer (eds), Transnational Legal Orders, (New York: Cambridge University Press, 2015).

26

M. Amstutz and V. Karavas, "Weltrecht: Ein Derridasches Monster", in Gralf-Peter Calliess, Andreas Fischer-Lescano, Dan Wielsch and Peer Zumbansen (eds), Soziologische Jurisprudenz. Festschrift für Gunther Teubner zum 65. Geburtstag, (Berlin: Walter de Gruyter, 2009), pp. 645-672.; B. de Sousa Santos, Towards a New Legal Common Sense: Law, Globalization, and Emancipation, 2nd edn., (Cambridge: Cambridge University Press, 2002), p. 437.

G. Palombella, "Global Law and the Law on the Globe. Layers, Legalities and the Rule of Law Principle", (2012) 2 Italian Journal of Public Law.

28 See P. Le Golf, “Global Law: A Legal Phenomenon Emerging from the Process of Globalization”, (2007) 14 Indiana Journal of Global Legal Studies, at 122 et seq. 
phenomena which provide essential building-blocks for global law at the same time as the notion of global law becomes broader by going beyond economic transactions and by stipulating a broader contextual impact "on society as such", rather than merely dealing with economic logics.

With the emphasis on the decentred universality of global law, a path is formed between the major positions dealing with global law to date: unifying and pluralist, or convergence and divergence oriented, perspectives. The unifying perspective has been most clearly developed from within international public law, i.e., positions which claim the existence of a singular hierarchy of legal norms in world society, typically seen as embedded in the law of the United Nations and an understanding of the UN Charter as a "constitution for the world" upon the basis of a claim to normative singularity. ${ }^{30}$ Another variant of this perspective has emerged through the claim that a singular legal system is constitutive for the world, as such, providing the (international) public law dimension of the legal system with a foundational position as the meta-system which constitutes society. ${ }^{31}$ But also within (international) private law, harmonising efforts have been central, as expressed in the attempt to establish a European civil code project ${ }^{32}$ and the call for a singular global commercial code. ${ }^{33}$ In contrast, pluralist perspectives have highlighted the fundamental a-centric and nonhierarchical nature of law in world society, emphasising a reworked conflict of laws perspectives for a fragmented world ${ }^{34}$ and the political dimension of legal diversity. ${ }^{35}$

${ }^{29}$ P. Le Golf, “Global Law: A Legal Phenomenon Emerging from the Process of Globalization”, (2007) 14 Indiana Journal of Global Legal Studies, at 122 et seq.

30 The Charter of the United Nations, 26 June 1945, available at: http://www.un.org/en/sections/un-charter/uncharter-full-text/ B Fassbinder we the people.

31 See C. Thornhill, A Sociology of Transnational Constitutions: The Social Foundations of the Post-National Legal Structure, (Cambridge: Cambridge University Press, 2016).

32 C. von Bar, E. Clive and H. Schulte-Nölke, Principles, Definitions and Model Rules of European Private Law: Draft Common Frame of Reference (DCFR), Volume 2, (Munich: Sellier, 2009).

33 O. Lando, "A Global Commercial Code”, (2004) 50 Recht der Internationalen Wirtschaft [R.I.W.], p. 161.

34 A. Fischer-Lescano and G. Teubner, Regime-Kollisionen: Zur Fragmentierung des Weltrechts, (Frankfurt am Main: Suhrkamp Verlag, 2006); M. Koskenniemi, "Legal Fragmentation(s) - An Essay on Fluidity and Form", in Gralf-Peter Calliess, Andreas Fischer-Lescano, Dan Wielsch and Peer Zumbansen (eds), Soziologische Jurisrudenz. Festschrift für Gunther Teubner zum 65. Geburtstag, (Berlin: Walter de Gruyter, 2009), pp. 795-810. See, also, the contributions in C. Joerges, P.F. Kjaer and T. Ralli, "A New Type of Conflicts Law as Constitutional Form in the Postnational Constellation", Special issue of (2011) 2 Transnational Legal Theory, pp. 153- 65.

35 N. Krisch, Beyond Constitutionalism: The Pluralist Structure of Postnational Law, (Oxford: Oxford University Press, 2010). 
This paradoxical unity of diversity can, however, be dissolved through a recourse to time, i.e., to a historical unfolding of the evolution of global law and global legal norms: a historical sociology of law approach aimed at analysing the functional pull leading to the emergence of global legal norms, combined with an evolutionary theory approach aimed at the transformation of global legal norms over time, and the internal and external effects produced through such norms. ${ }^{36}$ From such a perspective, a key insight is that global legal norms in a particular imperial, i.e., transcendental and universal, form preceded Westphalian (nation) state law. ${ }^{37}$ In addition, it can be observed that modern nation state law and the law of modern transnational governance co-emerged over a century-long process in a dialectically and mutually reinforcing relationship. ${ }^{38}$ This was a process which, simply put, came in two phases: first, the gradual emergence of territorial states in Western Europe from the sixteenth century onwards and the concomitant and simultaneous build-up of large-scale colonial empires with a global reach upon the basis of global colonial law. Second, the globalisation of statehood through the structural transformation initiated with the breakdown of the central and eastern European empires in the wake of World War I, which subsequently expanded throughout the globe via mid-twentieth century de-colonialisation, combined with and concomitant replacement of colonialism and colonial law with contemporary global governance and law.

\section{The Problem: The Prestation of Global Norms}

The structure of world society and global law as described above poses the classical sociological question, "how is society possible?"

${ }^{36}$ For the term historical sociology of law, see M. Rask Madsen and C. Thornhill, "Introduction: Law and the Formation of Modern Europe - Perspectives from the Historical Sociology of Law”, in Mikael Rask Madsen and Chirs Thornhill (eds): Law and the Formation of Modern Europe: Perspectives from the Sociology of Law, (Cambridge: Cambriidge University Press, 2014); For further reflections on its method specifically in relation to constitutional research, see C. Thornhill, A Sociology of Transnational Constitutions: The Social Foundations of the Post-National Legal Structure, (Cambridge: Cambridge University Press, 2016), $12 \mathrm{ff}$.

37 For this perspective, see, in particular, H. Brunkhorst, Critical Theory of Legal Revolutions: Evolutionary Perspectives, (London: Bloomsbury, 2014). Neil Walker also distinguishes a particular set of "historicaldiscursive approaches" to global law, but merely includes contemporary debate on global constitutionalism, constitutionalisation of international law and Global Administrative Law while essentially discarding any long-term historical perspective on global law. See N. Walker, Intimations of Global Law, (Cambridge: Cambridge University Press, 2015), p. 86ff.

P.F. Kjaer, Constitutionalism in the Global Realm - A Sociological Approach, (Abingdon: Routledge, 2014 - Paperback 2016), p. $31 \mathrm{ff}$.

39 P.F. Kjaer, Constitutionalism in the Global Realm - A Sociological Approach, (Abingdon: Routledge, 2014 - Paperback 2016), $17 \mathrm{ff}$.

40 G. Simmel, "Wie ist Gesellschaft möglich, 22 - 30", in G. Simmel, Untersuchungen über die Formen der Vergesellschaftung,(Berlin: Duncker \& Humboldt, 1908). Available at: 
centring of first the euro-centric, and, in our time, the western-centric world implies that, paradoxically, increased globalisation has increased, rather than diminished, the decentredness of world society. ${ }^{41}$ The issue of connectivity in the de-centred world society has therefore become a crucial, and maybe the most crucial, question of our time. This development might amount to a shift from a relative pre-dominance of logics of differentiation to an increased centrality logics of connectivity, i.e., inter-systemic connectivity. ${ }^{42}$ How is the probability of connectivity increased in relation to globally unfolding processes marked by an indeterminacy concerning which form of differentiation is the primary one in large segments of the world, and especially in situations which imply connectivity between components of communication situated in different contexts characterised by different constellations and primacies of the forms of differentiation?

As a reflection of this state of affairs, new types of intermediaries have emerged which tend to be network-based and rely on legal instruments for their stabilisation. ${ }^{43}$ Global supply chains, the global human rights regime and the climate change regime are examples of such intermediary structures. Strategically, they tend to be located within a single field or system such as the economic, the legal or the imaginary but, nonetheless, socially real system of the ecological environment, at the same time as their raison d'être is a double one: to produce internal coherency and connectivity within their respective functionally delineated areas on a global scale and externally to re-contextualise communicative components when they are transferred from one context to another, for example, from a context characterised by a primacy of functional differentiation to a context where such primacy is not manifest or vice versa. Their function is therefore to re-produce a paradoxical unity between functional fields and multiple social contexts while facilitating the transfer of condensed social components between such contexts.

In world society, the central issue of connectivity is therefore one of transfer. Following Rudolf Stichweh, the transfer of condensed social components (Sinnkomponente), as, for example, is known from the literature on legal transfers has at least five characteristics:

http://socio.ch/sim/soziologie/soz_1_ex1.htm.

${ }^{41}$ P.F. Kjaer, 'Facilitating Transfers: Regulatory Governance Frameworks as 'Rites of Passage', Contemporary Politics, 24, 5, 507 - 23, 2018.

42 P.F. Kjaer, "Systems in Context: On the Outcome of the Habermas/Luhmann-debate", (2006) Ancilla Iuris, pp. 66-77, at 77.

43 P.F. Kjaer, "The Metamorphosis of the Functional Synthesis: A Continental European Perspective on Governance, Law and the Political in the Transnational Space", (2010) Wisconsin Law Review, pp. 489-533. 
First, "the objects of transfer" are compact and distilled units of meaning, such as political/bureaucratic decisions, legal judgments, economic products, economic capital, and scientific or technological knowledge, all of which are clearly demarcated and possess a clear functional orientation.

Second, an act of transfer implies that the transferred unit(s) possess significant information value which is likely to be both recognisable and able to produce an impact in the receiving context.

Third, transfer implies boundary crossings, in so far as the units are dispatched from one context to another in a manner which is conceived of as a boundary crossing by both the dispatching and the receiving entities.

Fourth, transfer implies distance, either spatially and/or in terms of time.

Fifth, a certain permanency needs to be observable, typically based upon a repetition of the processes of the dispatch and receipt of the condensed social components which are similar, or at least recognisable as similar, over a longer time span.

Adding to Stichweh's list, one might, however, argue that norms of transfer and connectivity are constitutive for increasing the probability of successful transfers. When introducing the concept of world society, Luhmann advanced the "speculative hypothesis" that the emergence of world society would imply a relative reduction in the centrality of normative expectations and a relative increase in the centrality of cognitive expectations for the reproduction of world society. Social phenomena and processes which rely heavily on normative expectations, such as law, politics and morality, will, according to the expectation of Luhmann, lose out while the economy, technology and science, which, he argues, are characterised by a stronger reliance on cognitive expectations, will gain in centrality. ${ }^{45}$ Normative expectations are understood here as expectations which are upheld even if not fulfilled, thereby making them into contra-factually stabilised expectations, whereas cognitive expectations are understood as expectations which are changed in the event of non-

44 Rudolf Stichweh, Transfer in Sozialsystemen: Theoretische Überlegungen, pp. 1-13, in: Vanessa Duss and Nikolaus Linder et al. (eds), Rechtstransfer in der Geschichte, (Munich: Martin Meidenbauer, 2006). For a more detailed analysis of the issue of transfer, see P.F. Kjaer, 'Facilitating Transfers: Regulatory Governance Frameworks as 'Rites of Passage'", Contemporary Politics, 24, 5, 507 - 23, 2018.

45 N. Luhmann, "Die Weltgesellschaft", (1971) 57 Archiv für Rechts- und Sozialphilosophie, pp. 1-35. Reprinted in N. Luhmann, Soziologische Aufklärung 2. Aufsätze zur Theorie der Gesellschaft, (Opladen: Westdeutsche Verlag [1975] 2009), pp. 51-71. 
fulfilment. ${ }^{46}$ Twenty years before the publication of Jürgen Habermas' Between Facts and Norms (Faktizität und Geltung), which, as reflected in the original title, departs from a basic distinction between the factual and the normative, Luhmann had explicitly dismissed this distinction and replaced it with a distinction between normative and cognitive expectations. One of the advantages of this move is that it highlights that normative based contra-factual expectations are as real as cognitive expectations. The social world is characterised by a doubling of reality (Realitätsverdopplung) between the factually existing world and equally real communicatively articulated contra-factual visions of how the world should be.

While accepting the latter point concerning the doubling of reality and the equal real reality of normative based communication, one might, however, question the empirical validity of the former, concerning a relative reduction in the centrality of normativity, expressed through expectations, in world society. Globally unfolding processes do not rely on norms to a lesser extent than more locally or nationally embedded processes. ${ }^{48}$ Rather, they rely on a specific sub-type of norms which are different than those norms associated with local or national unfolding processes.

Within analytical philosophy, the core focus of norms is the issue of validity, i.e., whether a given norm is the right one or not. ${ }^{49}$ However, from a sociological perspective, the issue of validity is not the central question. Instead, two contrasting views appear to which one might add a third one which is particular relevant for globally unfolding processes:

- Coherency norms: within a "traditional" sociological perspective, norms tend to be seen as "instruments of collectivity", which is aimed at establishing coherency within a group, such as a tribe or a nation, through the prescription of specific actions, which are considered as desirable for the members of the group, prescriptions which are combined with an injunction, i.e., sanctions,

46 N. Luhmann, Rechtssoziologie Auflage: 4, (Wiesbaden: VS Verlag für Sozialwissenschaften; [1972] 2008), $40 \mathrm{ff}$.

47 N. Luhmann, “Quod Omnes Tangit: Remarks on Jürgen Habermas’ Legal Theory”, (1996) 17 Cardozo Law Review, pp. 883-899.

48 For more on this, see P.F. Kjaer, Constitutionalism in the Global Realm - A Sociological Approach, (Abingdon: Routledge, 2014 - Paperback 2016), p. 43ff.

49 See, for example, C. Korsgaard, The Sources of Normativity, (New York: Cambridge University Press, 1996). 
aimed at increasing the probability of future compliance with the norm by members of the group.

- Possibility norms: from this perspective, a norm introduces a distinction through a distance to the factually existing social reality as perceived in a given social context, through the introduction of a contra factual perspective. Possibility norms are, in direct opposition to coherency norms, instruments through which possible alternatives to the given social reality are unfolded, thereby marking possible futures in a manner which accentuates the openness, rather than the reticence, of the future.

- Connectivity norms: it is in contrast to the above two perspectives that one might introduce a third variant particularly suited for global contexts and which combines elements of the two previous ones while also going beyond them. Here, norms are considered as instruments aimed at facilitating the separation, transmission and incorporation of social components from one context to another. They are oriented towards the separation of social components from one social context, and provide guiding principles for their transmission and incorporation into other context(s) while relying on sanctions as well as inducing reflexive learning mechanisms vis-à-vis agents based in different contexts in order to increase contra-factually the probability of successful transfers in the future.

Connectivity norms increase possibilities, in so far as they are aimed at opening up the possibility of transfers at the same time as they are very much aimed at ensuring compatibility between processes unfolding in different contexts, a form of compatibility which implies that the stabilisation of processes of transfer, rather than the opening up of possibilities, moves to the forefront at the same time as compatibility does not amount to an intention of establishing coherency within a collectivity. But, at the same time, the notion of collectivity remains crucial in so far as increasing the probability of transfers implies the

50 J. Blake and K. Davis, "Norms, Values and Sanctions", in Robert E.L. Faris (ed), Handbook of Modern Sociology, (Chicago IL: Rand McNally, 1964), pp. 456-84; H. Hydén, Normvetenskap, Lund Studies in Sociology of Law, (Lund: Lund University, 2002), p. 96ff.; T. Parsons, The Structure of Social Action: A Study in Social Theory with Special Reference to a Group of Recent European Writers, (New York: Free Press, [1937] 1968).

51 N. Luhmann, Rechtssystem und Rechtsdogmatik, (Stuttgart: W. Kohlhammer, 1974); Christoph Möllers, Die Möglichkeit der Normen: Über eine Praxis jenseits von Moralität und Kausalität, (Berlin: Suhrkamp Verlag, 2015), p. 13f. 
development of internal images, or imaginaries, of collectivity within both the departing and receiving entities, which are typically manifested in legal constructions of collectivity, for example, through legal notions of "the nation" or "the community", which serves as the addressees of transfers.

The three dimensions of norms can also be seen as representing the three meaning dimensions of any social process, the substantial, the temporal, and the social dimensions. ${ }^{52}$ This again highlights that all three dimensions are always present within a given norm at the same time as the weight between them will differ in relation to different types of social processes and in different contextual circumstances. In praxis, the three dimensions of norms provide three different types of intentionality as expressed in the objects against which the norms are oriented, i.e., collectivities, articulated futures and acts of transfer, while each of them predominantly rely on three different types of instruments in their intentionality to bridge the factual and non-factuality: punishment, programmes articulating possible futures, or processes of maintaining connectivity.

Fig. 1: The three norm dimensions

\begin{tabular}{|l|l|l|l|}
\hline Norm dimensions & Coherency & Possibility & Connectivity \\
\hline Types of Meaning & Substantial & Time & Social \\
\hline $\begin{array}{l}\text { Objects of } \\
\text { intentionality }\end{array}$ & Collectivities & Articulated futures & Acts of transfer \\
\hline $\begin{array}{l}\text { Instruments of } \\
\text { realisation }\end{array}$ & Punishment & Programmes & Processes \\
\hline
\end{tabular}

Global legal norms are, according to the argument advanced here, overwhelmingly oriented towards the connectivity dimension, to the extent that one might argue that the prestation (Leistung) of global legal norms is to increase the probability of connectivity. This, for example, is the case in relation to the micro-economic constitution of the European Union, i.e., the constitution of the internal market. ${ }^{53}$ The internal market might be seen as a paradigmatic case of a legal constitution of a substantial social process, i.e., economic

52 N. Luhmann, Soziale Systeme, (Frankfurt: Suhrkamp Verlag, 1984), p. 112ff.

53 K. Tuori and K. Tuori, The Eurozone Crisis: A Constitutional Analysis, (Cambridge: Cambridge University Press, 2014), p. 13ff. 
exchange, which is aimed at increasing economic connectivity across diverse legallyentrenched contexts through the introduction of a hierarchy of norms as expressed through the four freedoms for goods, capital, services, and labour. A constitution which, furthermore, has no prescribed territorial limits as expressed in the inclusion of the European Economic Area (Iceland, Lichtenstein and Norway) as well as the partial inclusion of a whole string of other jurisdictions.

\section{From Colonialism to Global Supply Chains}

The internal market was already laid down in the Treaty of Rome of 1957 and its realisation was inherently linked to the implosion of both continental and overseas European empires and the progressive decentring of the euro-centric world which followed from these

implosions. ${ }^{54}$ It is therefore not surprising that what today is now known as European Union law has gained the status as the prototype of contemporary global law. ${ }^{55}$ In spite of the avantgarde position of European Union law, it only represents one species of global law, as legally-entrenched norms of connectivity can be observed throughout world society. Phenomena such as ecological communication, for example, in relation to climate change, or migration and global health management, for example, in relation to the epidemic diseases, the global tourism infrastructure as well as global infrastructures, for example, in relation to telecommunication and the Internet or aviation and shipping logistics, ${ }^{56}$ are all bound on norms of connectivity and global law.

Two other examples include global supply chains and the global human rights regime. The former is predominantly linked to (international) private law while the latter might be seen as originating from the (international) public law regime. However, the distinctiveness of the global human rights regimes when it comes to global law is, as we will return to in the final section, not so much linked to its origins within public law as to the way it provides a self-reflexive constitution of global law.

Global supply chains have become a central piece of infrastructure of the global economy. A typical definition of a supply chain characterises it as "a system of organizations, people, activities, information, and resources involved in moving a product or service from

54

H. Brunkhorst, Critical Theory of Legal Revolutions: Evolutionary Perspectives, (London: Bloomsbury, 2014); J.E. Fossum and A.J. Menéndez, The Constitution's Gift: A Constitutional Theory for a Democratic European Union, (Lanham MD: Rowman \& Littlefield, 2011).

55 N. Walker, Intimations of Global Law, (Cambridge: Cambridge University Press, 2015), p. 110ff.

56 B. Larkin, "The Politics and Poetics of Infrastructure", (2013) 42 Annual Review of Anthropology, pp. 32743. 
supplier to customer". ${ }^{57}$ A global supply chain furthermore implies that the chain crosses boundaries. From the background outlined above, this definition might be rephrased in the following manner:

"A network stretching from suppliers to customers which is engaged in the extraction, transmission and incorporation of condensed social components, i.e., capital, products and persons, from one societal context to another which can be either upstream or downstream or a combination hereof and implying boundary crossings, as part of the production of economic processes as well as the re-production of societal conditions allowing for the production of economic processes."

Global supply chains can furthermore be distinguished from global supply chain management, which might be defined as the second order dynamic stabilisation of global supply chains through organizational, managerial and legal instruments with the objective of increasing the probability of extraction, transmission and incorporation of condensed social components with economic value from one social context to another. The term "dynamic stabilisation" is crucial here, as it implies that the second order stabilising layer itself is moving, but at a slower pace than the focal first order processes that it is oriented towards. The distinction between supply chains and supply chain management is therefore tightly linked to the distinction between cognitive and normative structures of expectation in so far as cognitive expectations are constantly changing while normative expectations are characterised by a higher level of stability. In contrast to the Luhmannian view concerning the constancy, i.e., the non-changeable characteristics of normative expectations, it should, however, be noted that normative expectations also change over time, they only do so at a slower pace than cognitive expectations. Under modern conditions, the function of constitutions might therefore be understood to be its orientation towards bridging the time gap between first order cognitive expectations and second order normative expectations. ${ }^{58}$

In a standard text book, understanding global supply chains is largely a post-WWII phenomenon which gained increased relevance from the early 1980s onwards through a fundamental re-conceptualisation, implying increased formalisation as well as the emergence of (self-) reflective formations, i.e., through the emergence of the educational, legal and organisational praxis' specifically dealing with global supply chains. The post-WWII

\footnotetext{
57 https://en.wikipedia.org/wiki/Supply_chain.

58 P.F. Kjaer, Constitutionalism in the Global Realm - A Sociological Approach, (Abingdon: Routledge, 2014 - Paperback 2016)m p. 45 and 66ff.
} 
"invention" of global supply chains was, however, largely a "re-invention", as supply chains have, of course, been a constitutive element of commerce from day one just as global supply chains have been running at least since the emergence of European colonialism in the late fifteenth century. The slave trade, for example, coming out of Africa for both the Arabic world as well as the Americas also implied complex supply chains. ${ }^{59}$ The organisational dimension of colonialism might furthermore be considered as a particular form of global supply-chain management, as the core purpose of colonialism was the extraction, transmission and incorporation of condensed social components with a predominantly, albeit not exclusively, economic value. The central societal transformation related to the emergence of the contemporary form of global supply chains is therefore to be found in the structural transformation away from centre/periphery organised colonialism to functionallydifferentiated sectorial regimes within the global economic system.

In this context, tightly woven second order normative frameworks have emerged which has global supply chains as their point of orientation. A focus point has been the "principled approach to doing business" outlined in the ten principles of the UN Global Compact, which covers areas such as human rights, labour, environment and anticorruption. $^{60}$ Similar frameworks have been developed by UNCTAD and the OECD, just as NGOs and not least multinational firms engaged in global supply chains themselves have developed extensive normative frameworks aimed at regulating and stabilising such processes.

Luhmannian functional equivalence, which is not to be equalled with classical functionalism à la Durkheim, Malinowski, Merton or Parsons, has three implications: A) that a given problem can be addressed in multiple ways; B) that the essential problem for social processes with systemic traits is to connect to the next future operation; and C) that functional fields based on systemic logics seek to expand, i.e., universalising, their reach. ${ }^{62}$ Against this

59 P. Manning, "The Slave Trade: 'The Formal Dermographics of a Global System'”, in Joseph E. Inikori and Stanley L. Engerman (eds), The Atlantic Slave Trade: Effects on Economies, Societies and Peoples in Africa, the Americas, and Europe, (Durham NC: Duke University Press, 1992), pp. 117-44.

https://www.unglobalcompact.org/what-is-gc/mission/principles.

61 See, for example, L.C. Backer, "Economic Globalization and the Rise of Efficient Systems of Global Private Lawmaking: Wal-Mart as Global Legislator", (2007) 37 University of Connecticut Law Review, pp. 17391784.

62 For a pedagogical explanation of the concept of functional equivalence, see M. Hanna, "Between Law and Transnational Social Movement Organizations: Stabilizing Expectations of Global Public Goods", (2017) 44 Journal of Law and Society, pp. 345-3, at 352ff. More generally, see, also, N. Luhmann, Zweckbegriff und Systemrationalität: Über die Funktion von Zwecken in sozialen Systemen, (Frankfurt am Main: Suhrkamp 
background, and when considered as in-between structures oriented towards the problem of establishing a re-productive chain of extraction, transmission and incorporation, colonialism and global supply chains might be considered functionally equivalent structures, as they are aimed at addressing the same 'problem'. The contemporary form of global supply chains emerged in the wake of de-colonialisation acting as "substitutes" for the type of extraction, transmission and incorporation that unfolded through colonialism. This image is reinforced through the asymmetric relationship between upstream and downstream flows in both settings. Upstream is defined here as a move towards the end receiver, i.e., the consumer, of social components which are being increasingly condensed in the process of flowing upstream, while flow downstream characterises the opposite movement.

\section{From Colonial Law to Human Rights: Constitutionalising Connectivity}

Considerable variation can be observed between the legal foundations of, for example, Belgian, British, Danish, Dutch, French, German, Spanish and Portuguese colonial law, thereby opening up another "yet to be developed" scholarly field of comparative colonial law. ${ }^{63}$ A common feature of colonialism in its various forms was, however, that it obtained a second order normative, i.e., legal, stabilisation through the principles of dominium, i.e., ownership, iusgentium, i.e., the law of peoples, and bellum iustum, i.e., just war. ${ }^{64}$ For the economic dimension of colonialism, the central element was the development of a horizontal network of dominium based upon contracts and globally enforceable property rights combined with an equally global principle of unhindered commerce and access to resources. This upstream economic orientation was furthermore combined with a downstream principle concerning the unhindered access for Christian missionary activities. Instead of annexing territory, global capitalist exchanges and the transmission of religious values thereby became the legally-structured foundation of colonialism, making an upstream and downstream "right to extraction, transmission and incorporation" upon the basis of connectivity norms, the core principle on which global exchanges relied. ${ }^{65}$ However, due to the distinction between

Verlag, [1968] 1973), Stichweh, note 5 above.

63 O. Le Cour Grandmaison, "L'exception et la règle: sur le droit colonial français", (2005) 212 Diogène, p. 42; M. Koskenniemi, “Colonial Laws: Sources, Strategies and Lessons?”, (2016) 18 Journal of the History of International Law, pp. 248-277.

64 M. Koskenniemi "Empire and International Law: The Real Spanish Contribution", (2011) 61 University of Toronto Law Journal, pp. 1-36.

${ }^{65}$ M. Koskenniemi "Empire and International Law: The Real Spanish Contribution", (2011) 61 University of Toronto Law Journal, pp. 1-36, at 32ff. 
Christians and non-Christians on which the norms of connectivity relied, they opened up for and reinforced fundamentally asymmetric exchanges.

For the first phase of colonialism running from the late fifteenth century to the nationalisation of the Dutch East India Company in 1800, the French conquest of Algeria from 1830 onwards and the nationalization of the British East India Company in 1858, private law principles of commercial law provided the normative underpinning of colonialism. This only changed gradually with the increased transformation of colonialism into directly state-driven endeavours which increasingly shifted colonialism in the direction of direct territorial conquest and rule. This was, for example, reflected in the series of wars form 1821-1895 through which Dutch East India was transformed from a collection of more or less secure trading-posts into an entity characterised by the exercise of widespread territorial control; the consolidation of British rule of India through both direct and indirect means in the mid-nineteenth century; as well as the colonisation of the inner parts of Africa from the late 1870 s onwards, a development which gave the central impetus for the development of modern international law, providing a different normative underpinning to global connectivity while running in a complementary fashion to the previous developed principles of private colonialism. This shift implied an increased emphasis on the civilising responsibility of colonialism in a manner which went beyond the previous right to evangelism, and emphasised issues such as "societal progress" and "modernisation", instead. $^{66}$

Only with the third phase of globalisation emerging in the Post-WWII era did the combined element of global supply chains and modern human rights become the central factual and contra-factual infrastructure of global commerce. The history of global human rights is a long one which, in its modern version, can be traced back to at least the "Atlantic Revolutions", the revolutionary wave unfolding throughout Europe, and North and South America in the late eighteenth and early nineteenth centuries. ${ }^{67}$ Specifically for the global reach of human rights, the anti-slave trade movement has furthermore been identified as central, $^{68}$ while the opposite case has also been made upon the basis of the view that a

${ }^{66}$ For the classical reconstruction of this, see M. Koskenniemi, The Gentle Civilizer of Nations: The Rise and Fall of International Law 1870-1960, (Cambridge: Cambridge University Press, 2001).

${ }^{67}$ H. Brunkhorst, Critical Theory of Legal Revolutions: Evolutionary Perspectives, (London: Bloomsbury, 2014), $233 \mathrm{ff}$.

68 J. Martinez, The Slave Trade and the Origins of International Human Rights, (Oxford: Oxford University Press, 2014). 
fundamental shift in the purpose and set-up of human rights occurred in the latter half of the twentieth century as a consequence of de-decolonisation.

While the history of global human rights can thus be considered as one which is characterised by both continuities and discontinuities, the debate so far has been conducted by legal historians with little emphasis on sociology of law perspectives on the changed status of human rights in the third wave of globalisation. Within established and institutionally stable democracies, constitutionally-guaranteed basic rights are legal rights intrinsically linked to their operational realisation within the legal system upon the basis of the dual function of securing functional differentiation and individual autonomy. ${ }^{70}$ Global human rights have a different dual function both of which can be conceived of in constitutional terms:

Firstly: to secure the stabilisation, and with it the legitimisation, of regimes of transfer on a global scale. This, for example, is the case within company internal approaches ${ }^{71}$ as well as broader regime-based approaches to human rights as embedded in strategies of Corporate Social Responsibility. ${ }^{72}$ Such strategies are aimed at generalising communication across contextual boundaries, thereby allowing for multi-contextual embeddedness, i.e., the simultaneous compatibility of condensed social components with multiple social environments at different stages of a supply chain stream. The ten principles of the UN Global Compact and similar frameworks in such contexts are intended to provide a second order stabilisation of the legal and managerial set-up of globally-unfolding economic

69 S. Moyn, The Last Utopia. Human Rights in History, (Cambridge MA: Harvard University Press, 2010). For a "third way" between J. Martinez (note 71 above) and S. Moyn, see P. Alston, "Does the Past Matter? On the Origins of Human Rights An Analysis of Competing Histories of the Origins of International Human Rights Law", (2013) 126 Harvard Law Review, pp. 2043-81; N. Walker, Intimations of Global Law, (Cambridge: Cambridge University Press, 2015), p. 73ff. See, also, S.L.B. Jensen, The Making of International Human Rights: The 1960s, Decolonization, and the Reconstruction of Global Values, (Cambridge: Cambridge University Press, 2016).

70 N. Luhmann, Grundrechte als Institution. Ein Beitrag zur politischen Soziologie, (Berlin: Duncker \& Humblot, [1965]); G. Verschraegen, "Human Rights and Modern Society: A Sociological Analysis from the Perspective of Systems Theory", (2002) 29 Journal of Law and Society, pp. 258-281; idem, "Systems Theory and the Paradox of Human Rights", in Michael King and Chris Thornhill (eds), Luhmann on Law and Politics: Critical Appraisals and Applications, (Oxford-Portland OR: Hart Publishing, 2006), pp. 101125.

71 K.P. Japp, "Zur Funktion der Menschenrechte in der Weltgesellschaft - Niklas Luhmanns 'Grundrechte als Institution' Revisited ", in Bettina Heintz and Britta Leisering (eds), Menschenrechte in der Weltgesellschaft, Deutungswandel und Wirkungsweise eines globalen Leitwerts, (Frankfurt am Main: Campus Verlag, 2015), pp. 65-97.

72 K. Buhmann, "Business and Human Rights: Understanding the UN Guiding Principles from the Perspective of Transnational Business Governance Interactions”, (2015) 6 Transnational Legal Theory, pp. 399434. 
processes, thereby giving them a character as constitutional principles establishing hierarchies of norms vis-à-vis globally-unfolding economic processes.

Secondly: in contrast to previous colonial forms of justification and normative stabilisation, contemporary human rights-based forms are not formally based upon an asymmetric distinction, such as the colonial distinction between Christian and non-Christian. Factually, however, they tend to be characterised by in-built asymmetries in terms of resources and the articulation of values and direction. ${ }^{73}$ This gives global human rights an aspirational function in a broader societal as well as in a narrow legal sense in relation to their own realisation. Societally, global humans rights can be seen as oriented towards the realisation of functional differentiation and individual autonomy in the segments of the world which are characterised by métissage and creolisation. Legally, and this is what gives it a strategic position of constitutional worth within the legal system, is its function as a framework for the transfer of transfers, in so far as the function of global human rights regime is to facilitate the transfer of legal norms which are aimed at facilitating broader societal transfers of, for example, an economic or religious nature. Or to put it differently, the contra-factual orientation of the global human rights regime is to transpose legal norms which originally emerged in the

Western world on a global scale, i.e., to universalise the legal system of Western law, ${ }^{74}$ thereby constitutionalising the legal system's own global connectivity.

\section{Conclusion}

The core thesis advanced in this article is that global legal settings is characterised by a relative predominance of connectivity norms as opposed to coherency or possibility norms. Connectivity norms are oriented towards the facilitation of transfers of legally condensed social components of e.g. an economic or religious nature from one legally structured societal context to another and were the predominant form of norms in colonialism as well as in contemporary global governance. But while reproducing identical functions of transfer they rely on fundamentally different normative setups. They are therefore to be understood as functional but not as normative equivalents. The former relied on highly asymmetric distinctions, i.e. between Christians and non-Christians, while the latter subscribe to symmetric distinctions as embodied in the global human rights regime. A human rights

73 P.F. Kjaer, "The Metamorphosis of the Functional Synthesis: A Continental European Perspective on Governance, Law and the Political in the Transnational Space”, (2010) Wisconsin Law Review, pp. 489-533.

74 A. Supiot, "The Labyrinth of Human Rights. Credo or Common Resource?", (2003) New Left Review, no. 21, May-June, pp. 118-136. 
regime, which obtain a second-order constitutionalising function through its role in facilitating the transfer of law itself. 